\title{
Does the Concept of Enlightened Shareholder Value Succeed in Bridging the Gap between the Shareholders and Stakeholders Value Theories?
}

\author{
Dr. Osama Mustafa Mudawi \\ Ex. Academic staff, Department of Public Law, University of Dongola, Sudan \\ Legal Expert-Legal Affairs Department, Public Works Authority, Doha, Qatar \\ Email: drosamamus@hotmailcom \\ Dr. Elfadil Timan (Corresponding author) \\ Training Expert in Institute of Public Administration, P.O. Box-7677, Doha, Qatar \\ Associate Professor of Business Administration, University of Gezira, Sudan \\ E-mail: Elfadiltiman@yahoo.com
}

Received: May 24, 2017 Accepted: June 23, 2017

doi:10.5296/ber.v8i2.11271 URL: https://doi.org/10.5296/ber.v8i2.11271

\begin{abstract}
Purpose: The purpose of this article is to explore the main theories as to the corporate governance subject, and focus first on Shareholders and Stakeholders Value theories in order to identify their shortcomings. Next, the advantages and disadvantages of Enlightened Shareholder Value; including future perspectives on Enlightened Shareholder Value in light of the UK company Act 2006.

Methodology /approach: This article describes and compares the main theories with regard to the corporate governance subject. The following materials were referenced as part of this article: books, journal articles, cases, reports, legislations.

Findings: Based on the outcomes of the article there are advantages and disadvantages to Shareholders and Stakeholders Value theories. The former is considered a very narrow vision because its main aim is to gain profits for shareholders, it ignores stakeholders, there is a possible risk since managers and directors may abuse their delegations, and it costs more to monitor directors. Similarly, this article has been found that there are shortcomings to the
\end{abstract}


Stakeholders Value theory; for example, there is no clear hierarchy of stakeholders' interests, there is no one goal to achieve; it seems to demand less accountability from directors. Moreover, this article highlighted that the Enlightened Shareholder theory seems a better theory at present. Apparently, the success of this theory will depend on many factors: first, how the directors will apply the discretionary power with regard to section 172 (1) of CA 2006. Secondly, the interpretation of the courts about the duty of directors. Thirdly, the role of scholars improving this theory. Fourthly, how civil society will observe the application of this theory. Finally, recommended that further study should be done according to the recent practice.

Originality/value: This article contributes to increase the understanding of the theories of corporate governance and discover the best one for the time being.

Keywords: Corporate Governance, Shareholders Value Theory, Stakeholders Value theory, Enlightened Shareholder Value Theory, CA, ESV, ESG, PRI, UK and UN.

\section{Introduction}

Some researchers emphasised that the Corporate Governance is one of the most vital issues in business life (Joan, Keay \& Cerioni 2008) and is considered to be the core of business and investment. Nearly all developed and developing countries have adopted corporate governance regulations or issued new company laws (Ian Tricker 2015). The United Nations initiated its effort on corporate responsibility in 1999 under Secretary General of the UN with the Global Compact (United Nations Global Compact Annual Review - Anniversary 2010). The word 'governance' is derived from the Latin word gubernare, which means 'to steer', often referring to the steering of a vessel. This indicates that corporate governance is more concerned with guidance than control (Solomon, 2010). Generally, corporate governance concentrates on the policy of controlling and guiding a firm. Specifically, it focuses on the structures and procedures of governance, for instance, establishing the board of directors and internal auditing (Adeyeye, 2010). There are different theories concerned with corporate governance, for instance, Shareholders Value theory and Stakeholders Value theory, Stewardship theory, and Enlightened Shareholder Value (ESV), which was recently adopted in the UK with the Company Act 2006 (CA, 2006). Therefore, the UK is considered to be an example of a business culture which applies this theory. One researcher pointed out that before the 1997 election, the Labour Party announced that it would increase the competitiveness of UK business through improvement to corporate governance procedures (Ho, 2010). At that time the Blair government was concerned with ESV because it thought the worth of shareholders would only be maximised if stakeholders were considered. Therefore, in 1998 the Company Law Review Steering Group (CLRSG) was established to plan the structure of company law.

This article will focus first on Shareholders and Stakeholders Value theories in order to identify their shortcomings. Next, the advantages and disadvantages of ESV theory will be critically discussed, including future perspectives on this new approach in light of the CA 2006. This article argues that, because the ESV approach appears to be bridging the gap between Shareholders and Stakeholders Value theories, it is the best option at present. 
However, there are limitations to ESV theory which make predictions about its future success difficult.

\section{Shareholders Value Theory}

This section considers the concept of Shareholders Value theory. The advantages and disadvantages of this theory will be discussed in order to identify how ESV benefits from it.

\subsection{Definition}

Some researchers emphasized that the concept of a shareholder refers to whoever owns or possesses a property and can deal with it as they wish (Monks and Minow 2008). According to this theory, a corporation is a legal tool for shareholders to maximise profits from investment of their capital (Letza, Sun \& Kirkbride, 2004). Supporters of this theory argue that corporate governance has its foundation in individual private property, which leads to an appealing social system and an efficient economy (Letza etal., 2004). In addition, the role of managers is to create profit for shareholders. If there is conflict between the latter and non-shareholders, the interests of shareholders will prevail. This is expressed in the phrase 'shareholder primacy' (Keay, 2010).

\subsection{Advantages}

One argument in favour of the Shareholders Value theory is that it promotes the best environment for the creation of wealth and is the foundation for economic growth. Profit maximisation is a motive for investment, leading to the production of commodities and services and therefore to job creation (Kiarie, 2006). This theory supports the idea of private ownership and liberty to determine how shareholders invest their wealth (Kiarie 2006). Moreover, Shareholders are considered to be a vulnerable sector compared with others such as employees whose rights are protected by contracts and laws (Keay, 2011). It has been argued that not all stakeholders may be protected by law since there is no balance of power; therefore, some contracts may contain unfair conditions (Keay, 2011). Another advantage of this theory is that shareholders can appoint directors as agents to run the business, since it's impossible in commerce world contracts are run by shareholders, and directors have business knowledge and experience. Therefore, Shareholders are best suited to oversee directors and ensure that they fulfil their duties (Keay, 2008). Finally, this theory is precise and effective because there is one object, the creation of maximum profit, and therefore it is easy to manage a company. As a result a court or shareholder may easily decide upon the behaviour of directors (Keay, 2008).

\subsection{Disadvantages}

One of the main disadvantages of the Shareholders Value theory is that it has a very narrow vision (Sjafjell, 2009). It is described as selfish because their main aim is to increase shareholders' profits. As a result, the theory does not allow for the consideration of others such as customers or the environment (Fisher, 2009). It has been claimed that one reason to consider the latter is that companies should provide social functions (Keay, 2011). Furthermore, one may argue that the Shareholders Value theory does not ignore stakeholders 
since the legality of stakeholders is recognized according to applicable laws, and by focusing on shareholder interests a company may indirectly promote the interest of stakeholders (Ho, 2010). For instance, by paying taxes, it may contribute generally to the total social welfare. Another disadvantage of this theory is that there is a risk that managers and director may abuse their powers for their own benefit. Moreover, it seems to be hard to monitor directors (Letza etal., 2004). Furthermore, the principal and the agent may have different thoughts as to the risk (Letza etal., 2004). Finally, it is an imperfect theory because it is concerned with short-term strategy (Kiarie, 2006). Arguably, this approach is concerned with share price and does not reflect the real value of the company's assets (Keay, 2011). An apparently valuable company may collapse suddenly.

\section{Stakeholders Value Theory}

This section considers the concept of Stakeholders Value theory. The advantages and disadvantages of this theory will be considered to show how ESV benefits from it.

\subsection{Definition}

This theory focuses on all parties affected by a company's activities (Fisher, 2009). In other words, its objective considers many things, for instance, the environment. It has been argued that these concerns lead to business success (Letza etal., 2004). There are many definitions of Stakeholders Value theory. For instance, Freeman (2010) defines a Stakeholder as: '[a]ny group or individual who can affect or is affected by the achievement of the corporation's purpose'. This theory requires employees and other stakeholders to participate in decision-making (Kiarie, 2006). The Qatar Corporate Governance Code (2016) provides some stakeholders as examples and leaves the door open to add any other stakeholders. This main purpose of this theory is inclusion and wider responsibility and ensures that all groups participating in the success should be considered since all members work jointly for a common object (Keay, 2010).

\subsection{Advantages}

One argument in favour of this theory is that it adopts long-term policy. It has been claimed that this may lead to an increase in the profitability and stability of a company by supporting the market confidence and economic effectiveness (Letza etal., 2004). Another advantage of this theory is that it is not concerned only with profit maximisation and therefore the company is free to deal with what is considered important by the consumers or employees (Fisher, 2009). Finally, advocates have argued that prioritising ethical, social and environmental responsibility may increase profits by reducing costs, for instance, by dropping wastage and preservation a reputation (Kiarie, 2006).

\subsection{Disadvantages}

There are several possible disadvantages to this theory. It fails to offer a comprehensive objective of the firm and therefore, leaves directors without clear guidelines. As a result the company may suffer managerial uncertainty, conflicts, and inefficiency, leaving it unable to compete effectively (Andriof, 2002). It has been argued that the foundation of this theory 
includes the doctrine of fairness, and stakeholders should be treated with humanity (Keay, 2011). Nevertheless, it has been argued that 'fairness' is not a clear concept since there are no objective standards. Moreover, as to humanity, Keay (2011) states, stakeholders such as the environment are not generally considered persons. Another disadvantage is that, the directors may not be subject to accountability by any specific group of stakeholders since there is no internal control (Sealy \& Worthington, 2008). Arguably, this grants directors a broad discretion which may lead to abuse (Kiarie, 2006), leaving them subject only to market conditions (Andriof, 2002). In addition, there is a lack of clarity over the hierarchy or priority of stakeholders (Keay \& Zhang, 2011). In other words, there is difficulty in determining the grade of interest of each stakeholder; for instance, some employees require more salary than others.

Moreover, this theory may also be unworkable since membership of stakeholders and their roles are not specified (Keay, 2011). Advocates have argued that the wider scope of the theory is a positive element since more stakeholders may be included (Keay, 2011). Finally, this theory may be disadvantageous in altering the power of shareholders due to moves to grant stakeholders the right to participate in making decisions and selecting the board of directors (Kiarie, 2006).

\section{Enlightened Shareholder Value Theory- New Approach}

This section will define and discuss the concept of ESV. In addition, the advantages and disadvantages of this theory will be discussed critically in light of s.172 (1) of CA 2006, which contains codification of ESV and is considered a good example thereof (Andreadakis, 2010). Moreover, the UK has vital influence on other states.

\subsection{Definition}

One researcher pointed out that as a result of the failure of Stakeholders Value theory to achieve the expected result in the new corporate field, ESV appears as one of the options (Andreadakis, 2010). ESV aims to achieve profit maximisation as the goal of a company, but this interest is subject to consideration of the interests of stakeholders (Kiarie, 2006). It has been argued that this is the best method to ensure sustainability and secure generally prosperity and welfare (Kiarie, 2006). In addition, ESV is different from Stakeholders Value theory since the former considers the interests of the Shareholders as priority. However, as with Stakeholders Value theory, no member has direct priority over others (Andreadakis, 2010). Based on this approach, directors are required to follow long-term strategy in considering the interests of a firm (Akinpelu, 2011). Therefore, the main difference between ESV and Shareholders Value theory is that the former follows long-term strategy (Andreadakis, 2010). It is considered as a 'third way' because it was derived by merging aspects of the Shareholders and Stakeholder Value theories (Williams \& Conley, 2005). It is important to consider stakeholders in order to achieve the aims of the company. For instance, good relations with communities are considered as a 'social license to operate' (Cerioni, 2008). Moreover, this relationship leads companies to contribute in local community policies and crisis solutions and can create good opportunities for the company to put forward its arguments about any problems. Similarly, if the company does not concern with 
environmental issues, this may affect its reputation among stakeholders' members and offer competitors the chance to increase their business (Cerioni, 2008). Arguably, this theory in line with the United Nations-backed Principles for Responsible Investment Initiative (PRI) which launched in 2006, its aim is to understand the implications of sustainability for investors and support signatories to integrate environmental, social and governance (ESG) subjects into institutional investment (Zarbafi, 2011).

\subsection{Advantages}

There are several arguments in favour of this theory. The supporters of ESV for the CA 2006 argue that adopting this approach would not require any change in the tasks of directors nor in the main object of the company (The Company Law Review Steering Group, 1999). This statement criticised that, ESV is considered a significant step from stubborn shareholder primacy (Andreadakis, 2010). As abovementioned, directors must consider stakeholders' interests. Another advantage is that, unlike Shareholders Value theory, ESV focuses on long-term benefits by considering inside and outside constituencies which leads to sustainability of the company (Keay, 2007). Apparently, ESV gives employees some confidence that the company may not terminate their contacts in the short term, and this confidence is reflected in positive contributions to production. In addition, this may lead companies to expand their reputation and to cooperate with business contributors such as creditors (Clarke, 2007). Furthermore, in countries which have codified ESV, directors have legal permission to consider stakeholders without fear of being sued by shareholders (Keay, 2007). It has been argued that ESV partially responds to the problem of stakeholders since its priority is still to create maximum profit for shareholders (Ho, 2010). It has been claimed that this maximum profit motive is considered to be one factor in attracting investors (Kiarie, 2006).

Moreover, others have argued that stakeholders' interests have generally been better protected and enhanced through laws rather than corporate governance, for instance, through environmental and labour laws. In addition, employees often make contracts with firms (Ho, 2010). However, sometimes laws do not cover all stakeholders, and contracts may be inequitable. Another advantage of ESV is that it may help companies retain employees because they are considered valuable in order to achieve the company's success (Clarke, 2007). Employees have more loyalty to a company that provides them with long job contracts and training. Finally, ESV does not require a company to make balance between stakeholders, which may reduce any abuse of the power by directors (Keay, 2007). Therefore, ESV appears to have more accountability compared with Stakeholders Value Theory.

\subsection{Disadvantages}

One of the disadvantages of ESV is that stakeholders are not clearly defined and there is no hierarchy among them, a shortcoming that puts more pressure on directors (Explanatory Notes on the Companies Act 2006, para. 326) states that'this list is not exhaustive, but highlights areas of particular importance which reflect wider expectations of responsible business behaviour, such as the interests of the company's employees and the impact of the company's operations on the community and the environment'. As a result, it may be difficult 
for directors to organise stakeholders according to priority so as to promote the success of the company. In addition, it is not clear what happens if the interests of one or more stakeholders come into conflict with promoting the success of the company? Keay (2010, p. 18) offers the criticism that: " $\mathrm{t}]$ he legislation fails to provide little or no guidance either to directors that have to make corporate decisions, or to the courts which may be asked to review what directors have done'. This drawback may lead companies to grant directors wide discretionary power and to demand less accountability. It may be argued that considering stakeholder 'adds an element of corporate social responsibility' (Andreadakis, 2010). In addition, the question remains open how directors will balance conflicts among stakeholders (Kiarie, 2006). Another disadvantage of ESV is that no real rights are granted to stakeholders since there is less enforceability. For instance, (Company Act 2006,s. 172 (1)), which provides that 'Duty to promote the success of the company: (1)A director of a company must act in the way he considers, in good faith, would be most likely to promote the success of the company for the benefit of its members as a whole, and in doing so have regard (amongst other matters) to (a) the likely consequences of any decision in the long term,(b) the interests of the company's employees, (c)the need to foster the company's business relationships with suppliers, customers and others, (d)the impact of the company's operations on the community and the environment, (e)the desirability of the company maintaining a reputation for high standards of business conduct, and (f) the need to act fairly as between members of the company'. This section gives very little protection against the violation of Stakeholders' rights since it requires directors to do their duty in good faith while promoting the success of the company (Kiarie, 2006). Therefore, directors may discharge this duty without needing to make strong arguments. For example, if they allege a subject was discussed at a board meeting, this assertion seems to be sufficient for them to claim that the decision was taken in good faith (Ho, 2010).

Furthermore, (Company Act 2006, s. 172 (1)) does not grant stakeholders the right to bring a suit about any allegation concerning a breach of their interests (Payne, 2011). It has suggested that it may be useful for courts to adopt a positive interpretation with regard to stakeholders' interests. However, the effect of this suggestion seems limited since stakeholders have no right to make a claim. In addition, section 172 (1) was criticised for lacking any methods to enforce its breach by directors (Keay, 2010). Generally, there are no penalties. Therefore, the directors may become less enthusiastic about considering stakeholders' interests. Moreover, the criticism has been made that section 172 (1) does not contribute anything revolutionary since there is nothing in common law to prohibit directors from considering stakeholders' interests, provided that the directors deal in 'good faith in the best interests of the company as a whole' (Keay, 2010). However, when ESV was adopted by the CA 2006, it was considered to bring something totally new to corporate governance (Re West Coast Capital (LIOS) Ltd, 2008). For instance, in all companies subject to the CA 2006, the directors must consider a long-term policy and consider stakeholders' interests. The question may arise, however, whether common law already required this duty towards stakeholders before the act was passed? 


\section{Future Perspectives of ESV (New Approach)}

Based on the above discussion, ESV seems a better theory at present than either of the alternatives, and it appears to have succeeded to some extent in filling the gap between the Shareholders and Stakeholders Value theories by merging the advantages of both. It offers a better option (Kiarie, 2006) since it requires consideration of stakeholders' interests and long-term sustainability of the company, modifications which correct some of the shortcomings in Shareholders Value theory. On the other hand, ESV addresses drawbacks in Stakeholders Value theory, by adopting the maximum profit motive in favour of shareholders, which promotes efficiency and responsibility. Therefore, Kiarie (2006, p. 342) states that: 'ESV kills two birds with one stone since stakeholders get more consideration and shareholders maintain the profit maximisation goal and remain to hold directors accountable'. However, ESV is not free from shortcomings, as discussed above.

Moreover, it is would be useful to discuss the future perspectives of ESV by concentrating more on (Company Act 2006, s. 172 (1)). As abovementioned, this is a good illustration which contains ESV. It seems directors may face some difficulties while applying it. Similarly, courts may find some complexities in interpreting this section (Joan etal., 2008). For instance, the phrase 'promote the success of the company' is not clear. Does it refer to profit or perpetual of the company? (Keay, 2010). However, Cerioni (2008, p. 2) pointed out that '[s]uccess means what the members collectively want the company to achieve. For a commercial company, success will usually mean long-term increase in value'. It has been argued that what members prefer may differ from one group to another. As Hannigan and Prentice (2009, p. 31) observe: 'The members ... often have different views'. In addition, the question may arise: for whom is this success? Section 172 (1) states: 'for the benefit of its members as a whole'. Nevertheless, this is not clear since a company is a legal entity separate from its shareholders. Moreover, the phrase have regard to' is not obvious. Does it mean just to think about or to take into account? There is no firm obligation to consider stakeholders since material elements do not incorporate in s 172 (1). In contracts to, draft Bill a clause 2 (b) of Schedule 2 A mentions 'all the material factors'. Keay (2007, p.598) states that:

The only element that delimits what directors can or cannot do is their good faith, and this seems to be a significant departure from the terms of the draft Bill annexed to the 2002 White Paper, particularly clause 2(b) of Schedule 2, that said that 'in deciding what would be most likely to promote that success [of the company], [a director must] take account in good faith of all the material factors that it is practicable in the circumstances for him to identify.' Then 'material factors' were defined as:(a) The likely consequences (short and long term) of the actions open to the director, so far as a person of care and skill would consider them relevant; and (b) All such factors as a person of care and skill would consider them relevant.

Moreover, the list mentioned in section 172 (1) as to stakeholders is not conclusive, and this lack of clarity leads to increased pressure on directors. Pichet (2011), states that:

Which employees should be viewed as stakeholders - permanent staff members, people on short-term contracts, temps, interns, potential recruits and/or pensioners? How far can this go? What about when people belong to several stakeholder categories at once, i.e. they can be 
both customers and employees, raising questions about the breakdown between these two roles. Even more complicated is figuring out who is supposed to speak on future generations' behalf.

Nevertheless, this section 'adds an element of corporate social responsibility' (Andreadakis, 2010). Furthermore, it may be difficult for directors to prioritise this list so as to promote the success of the company. In addition, it is not clear what should happen if the interests of one or more stakeholders conflict with promoting the success of the company (Keay, 2010). Keay (2010, p. 18) makes the criticism that: ' $[\mathrm{t}]$ he legislation fails to provide little or no guidance either to directors that have to make corporate decisions, or to the courts which may be asked to review what directors have done'. It has been argued that this limitation may lead companies to grant directors wide discretion power and less accountability.

Furthermore, another argument against this theory is that the phrase 'the long term' is not clear, Keay (2010, p. 387) states that: '[g]enerally speaking, the favouring of long-term gains tends to be the position of many finance theorists today. But the concept of long term is not precise.' For instance, two years may be considered long term. On the other hand, some may assume that long term means at least five years. However, this ambiguity may give directors discretionary power to consider what long term means (Keay, 2010). It has argued that ESV sets out guidance about the interests of different stakeholders with what is theoretically called 'long-term shareholder value'. In other words, directors are required to achieve long-term strategy while distinguishing among stakeholders (Kiarie, 2006). This may not be sufficient guidance since there still is not an exclusive list of stakeholders. Moreover, section 172 (1) requires directors to act in good faith to promote the success of the company and to consider factors subject to this section, such as creditors.

In (GHLM Trading Ltd v Maroo \& Ors, 2012) the court states that:

To my mind, questions of breach and remedy need to be distinguished. A director of a company has a duty to act "in the way he considers, in good faith, would be most likely to promote the success of the company for the benefit of its members as a whole" (see section 172 of the Companies Act 2006). Where creditors' interests are relevant, it will similarly, in my view, be a director's duty to have regard to the interests of the creditors as a class. If a director acts to advance the interests of a particular creditor, without believing the action to be in the interests of creditors as a class, it seems to me that he will commit a breach of duty.

This duty is explained in the (Explanatory Notes on the Companies Act 2006, para 328 ): ' $[\mathrm{t}]$ he duty does not require a director to do more than good faith and the duty to exercise reasonable care, skill and diligence would require...'. It appears from the above explanation that there is no duty required rather than acting in good faith; therefore, directors may easily contend that they doing their duties pursuant to the Company Act 2006. As Keay ( 2011, p. 143 ) pointed out:

Primarily the test of whether a director has acted in good faith or not has been subjective, and provided that courts believe directors when they give evidence that they believed in good faith that the action that was taken was in the best interests of the company, the directors 
would not be liable for breach, this is even if a director acted unreasonably (in the view of the judge).

It is useful, therefore, to adopt objective standards to assess the conduct of directors. Moreover, if the courts approve the directors' breach of their duty, it seems there is a bit enforceability since there is no mechanism to encourage directors to follow the rules, for example, by imposing punishments or sending them to jail. Moreover, as has been pointed out herein, it seems that the CA 2006 does not impose a true duty on directors to consider the stakeholders because directors are not required to do more than behave in good faith (Kiarie, 2006). Apparently, as abovementioned directors may disencumber this duty easily. Therefore, the duty to consider stakeholders seems like a voluntary act. The question may be raised whether outcomes of ESV under UK law are different from Corporate Social Responsibility (CSR). The latter is defined by Commission, (2001) as 'A concept whereby companies integrate social and environmental concerns in their business operations and in their interaction with their stakeholders on a voluntary basis'. Section 172 (1) does not permit stakeholders any right to take legal action about any allegation regarding a violation of their interests (Keay, 2010). It has been suggested that the courts insist on a positive interpretation of the law which is supportive of stakeholders' interests. This may be difficult since some directors may not take legal action against others directors because it would mean that all directors may be liable, so logically they would not want to harm themselves or may feel uncomfortable suing some members (Keay, 2011). Similarly, shareholders may feel that the acts of the directors benefit their interests (Keay, 2011). Moreover, if even some shareholders or the company desire to sue the directors it is difficult to get permission from a court to make a case (Keay, 2011). It has been suggested that it may be more practical to modify the CA 2006 to grant stakeholders clear rights and the right to make claims about these rights if they are breached by directors.

Furthermore, (Company Act 2006 s., 471) provides that a Directors' Report should contain a Business Review which reflects how the directors carry out their legal duty under section 172 (1). The aim of the Business Review is to assist the members of the company in evaluating the performance of the directors, for instance, with regard to employees (Company Act 2006 s., 471 (2). Some have argued that the effect of the Business Review is questionable since it may not produce a true supervision from all members concerned (Keay, 2007). Apparently, this report may encourage the directors to deal with section 172 (1) positively in the future, since it enables members to monitor the directors (Joan etal., 2008). It has been suggested that, to strengthen the effect of this Business Review, it may be useful to send a copy to an independent committee for further monitoring such as the committee relating to (Agreement on Trade-Related Investment Measures (TRIMs) 1994, Article 7(3)) which states: 'The Committee shall monitor the operation and implementation of this Agreement and shall report thereon annually to the Council for Trade in Goods'.

Based on the above discussion, it is difficult to predict the future of ESV in light of section 172 (1), since there is limited or no related case law concerning ESV (Keay, 2010). Furthermore, the implications of ESV will not be easy to determine since the United Kingdom, before enforcing CA 2006, traditionally followed the Shareholders Value theory 
(Kiarie, 2006). Generally, the duties of directors are ambiguous and section 172 (1) offers less guidance. Nevertheless, it seems the success of ESV will be based on four factors. Firstly, how will the directors apply this section or theory in general? As abovementioned there is no clarity as to how section 172 (1) grants directors discretionary authority; they may use it positively or negatively. Secondly, how will courts deal with cases related to these issues? (Explanatory Notes on the Companies Act 2006, para. 36). In other words, will the courts explain the ambiguity in favour of the ESV? Thirdly, what will be the contributions of scholars in developing this theory through further research? Finally, the role of civil society to observe the application of ESV, in particular Non Governmental Organisations (NGOs). For instance, with regard to the CA 2006 (NGOs, 2006) emphasise that: '... [f]or future campaigning in 2007 and beyond so the right measures are put in place that will ensure companies are made accountable for their impact on people and planet. This will include how the Companies Act 2006 works in practice ...'. In addition, it seems in democratic countries such as the UK, NGOs may play a significant role which may lead to positive implications of $\mathrm{ESV}$ in the future.

\section{Conclusion}

The topic of corporate governance is considered to be one of the most vital issues in commerce. There are many theories about International Corporate Governance, for instance, Shareholders and Stakeholders Value theories and ESV. This article has found that there are advantages and disadvantages to Shareholders and Stakeholders Value theories. The former is considered a very narrow vision because its main aim is to gain profits for shareholders. Moreover, it ignores stakeholders, for instance, the environment. Furthermore, there is a possible risk since managers and directors may abuse their delegations to achieve benefits for themselves, and it costs more to monitor directors. Similarly, this article has been found that there are shortcomings to the Stakeholders Value theory; for example, there is no clear hierarchy of stakeholders' interests. Furthermore, there is no one goal to achieve; therefore, it seems to demand less accountability from directors. Moreover, this article highlighted that ESV seems a better theory at present since it seems to have succeeded to some extent in filling the gap between the Shareholders and Stakeholders Value theories. In addition, this article has explored the ambiguity about ESV as set forth in section 172 (1) of UK Company Act 2006, for instance, phrases 'long term', and 'success of the company'. This article has suggested that more explanation of section 172 (1) is required, it useful to adopt objective standards to assess the conduct of directors, and it may be necessary to establish an independent committee to monitor Business Reviews under section 417.

Moreover, as to the future of this theory, this article has found that too early to make a judgment. Apparently, the success of this theory will depend on many factors: first, how the directors will apply the discretionary power with regard to section 172 (1). Secondly, the interpretation of the court about the duty of directors. Thirdly, the role of scholars improving this theory through further research. Finally, how civil society will observe the application of ESV, in particular Non-Governmental Organisations (NGOs). Therefore, recommended that further study should be done according to the recent practice to explore the advantages and disadvantages of ESV and to what extent has it succeeded in filling the gap between the 
Shareholders and Stakeholders Value theories.

\section{References}

Adeyeye, A. (2010). The limitations of corporate governance in the CSR agenda, Company Lawyer, 31(4), 114-115.

Akinpelu, O. (2011). Corporate governance framework in nigeria: An International review . Indiana ,USA: iUniverse.

Andreadakis, S. (2010). Corporate governance in the aftermath of the scandals: The EU response and the role of ethics (Doctoral dissertation University of Leicester, Leicester, England). Retrieved from

https://lra.le.ac.uk/bits tream/2381/9532/2/Andreadakis\%20PhD\%20Thesis.pdf

Andriof, J. (Ed.). (2002). Unfolding Stakeholder Thinking: Theory, Responsibility and Engagement. Vol. 1. Sheffield: Greenleaf.

Cerioni, L. (2008). The Success of the Company in section 172(1) of the UK Companies Act 2006: Towards an 'Enligthened Directors' Primacy?, Original Law Review, 4(1), 2-33.

Clarke, T. (2007). International corporate governance: A comparative approach. London, UK: Routledge. https://doi.org/10.4324/9780203300725

Commission. (2001). Green paper: Promoting a european framework for corporate social responsibility' COM. Retrieved from

http://eur-lex.europa.eu/LexUriServ/LexU riServ.do?uri=COM:2001:0366:FIN:en:PDF

Fisher, D. (2009). The enlightened shareholder - leaving stakeholders in the dark: Will Section 172(1) of the companies act 2006 make directors considerthe impact of their decisions on third parties?, International Company and Commercial Law Review, 20(1), $10-12$.

Freeman, R. (2010). Strategic management: A stakeholder approach. Cambridge, UK: Cambridge University Press. https://doi.org/10.1017/CBO9781139192675

Hannigan, B., \& Dan, P. (2009). Hannigan and prentice: The Companies act 2006 commentary. Butterworths, UK: LexisNexis.

Ho, K. (2010). Director's Duty to Promote the Success of the Company: Should Hong Kong Implement a Similar Provision, Journal of Corporate Law Studies, 10(1), 17-33.

https://doi.org/10.1080/14735970.2010.11419819

Ho, V. (2010). Enlightened Shareholder Value: Corporate Governance Beyond the Shareholder-Stakeholder Divide. The Journal of Corporation, 36(1), 59-112.

Ian Tricker, R. ( 2015). Corporate governance: Principles, policies, and practices. Oxford, UK: Oxford University Press.

Joan, L., Keay, A., \& Cerioni, L. (2008). Legal Practitioners, enlightened shareholder value and the shaping of corporate governance, Journal of Corporate Law Studies, 8(1). 
Keay, A. ( 2011). The Corporate Objective. Edward Elgar \& Cheltenham. https://doi.org/10.4337/9780857933126

Keay, A. (2007). Tackling the issue of the corporate objective: An analysis of the united kingdom's enlightened shareholder value approach, Sydney Law Review, 29(4), 577-612.

Keay, A. (2008). Ascertaining the corporate objective: An entity maximisation and sustainability model, Modern Law Review, 71(5), 663-698.

https://doi.org/10.1111/j.1468-2230.2008.00711.x

Keay, A. (2010). Shareholder primacy in corporate law: Can it survive? should it survive?, European Company and Financial Law Review,7(3), 369-413.

https://doi.org/10.1515/ecfr.2010.369

Keay, A. (2010). The duty to promote the success of the company: Is it fit for purpose? Retrieved from .https://papers.ssrn.com/sol3/papers.cfm?abstract_id=1662411

Keay, A. (2011). Good faith and directors' duty to promote the success of their company, Comp. Law, 32(5), 138-143.

Keay, A. (2011). Moving towards stakeholderism? constituency statutes, enlightened shareholder value, and all that: Much Ado about Little?, European Business Law Review, 22(1), 1-49.

Keay, A. (2011). The global financial crisis: Risk, shareholder pressure, and short-termism in financial institutions - does enlightened shareholder value offer a panacea?, Law and Financial Markets Review, 5(6), 435-448. https://doi.org/10.5235/175214411798411095

Keay, A., \& Zhang, H. (2011). An analysis of enlightened shareholder value in light of ex post opportunism and incomplete law, European Company and Financial Law Review, 8(4), 445-475. https://doi.org/10.1515/ECFR.2011.445

Kiarie, S. (2006). At crossroads: shareholder value, stakeholder value and enlightened shareholder value: Which road should the united kingdom take?, International Company and Commercial Law Review, 17(11), 329-343.

Letza, S., Sun, X., \& Kirkbride, J. (2004). Shareholding versus stakeholding: a critical review of corporate governance, Corporate Governance, 12(3), 62-242.

https://doi.org/10.1111/j.1467-8683.2004.00367.x

Monks, R., \& Nell, M. (2008). Corporate governance. (4th ed.) .Chichester, UK: Wiley\& Chichester.

NGOs. (2006). Right corporate wrongs: The Companies Act (formerly the Companies Bill) An update for supporters on the outcome. Retrieved October from http://corporate-responsibility.org.

Payne, J. (2011). Minority shareholder protection in takeovers: A UK perspective, European Company and Financial Law Review, 8(2), 145-173. https://doi.org/10.1515/ecfr.2011.145 


\section{Macrothink}

Business and Economic Research ISSN 2162-4860 2018, Vol. 8, No. 2

Pichet, E. (2011). Enlightened shareholder theory: Whose interests should be served by the supporters of corporate governance? CORPORATE OWNERSHIP \& CONTROL, 8, 353-362. https://doi.org/10.22495/cocv8i2c3p3

Sealy, L., \& Sarah, W. (2008). Cases and materials in company law. Oxford, UK: Oxford University Press.

Sjafjell, B. (2009). Towards a sustainable european company law: A normative analysis of the objectives of eu law, with the takeover directive as a test case, 1. The Netherlands: Kluwer Law International.

Solomon, J. (2010). Corporate governance and accountability) 3rd ed. (Chichester, UK: John Wiley

The Company Law Review Steering Group. (1999). Modern company law for a competitive economy: The Strategic framework. Retrieved from http://www.bis.gov.uk/files/file23279.pdf

The Department of Trade and Industry. (2006). Explanatory notes on the companies act 2006. Retrieved from http://www.legislation.gov.uk/ukpga/2006/46/notes/division/6/2

UN. (2010). United Nations Global Compact Annual Review - Anniversary . Retrieved from https://www.unglobalcompact.org/docs/news_events/8.1/UNGC_Annual_Review_2010.pdf

Williams, C., \& Conley, J. (2005). An emerging Third Way?: The Erosion of the Anglo-American Shareholder Value Construct, Cornell International Law Journal, 38(2), 494-551.

WTO. (1994). Agreement on Trade-Related Investment Measures. Retrieved from https://www.wto.org/english/docs_e/legal_e/18-trims.pdf

Zarbafi, E. (2011). Responsible investment and the claim of corporate change: A sensemaking perspective on how institutional investors may drive corporate social responsibility. Wiesbaden, Garmeny : Gabler Verlag.

\section{Cases:}

GHLM Trading Ltd v Maroo \& Ors [2012]EWHC 61

Re West Coast Capital (LIOS) Ltd. (2008) CSOH 72

\section{Legislation:}

Qatar Financial Markets Authority. (2016). Qatar Corporate governance code for companies listed in the main markets. Retrieved from

https://www.qe.com.qa/documents/20181/458121/Corporate+Governance+-+QFMA.pdf/c10 8b916-c0a1-b4fc-d6f7-3efe7e0fce75

United Kingdom. (2006). Company Act. Retrieved from 2017. https://www.legislation.gov.uk/ukpga/2006/46/contents 


\section{Copyright Disclaimer}

Copyright for this article is retained by the author(s), with first publication rights granted to the journal.

This is an open-access article distributed under the terms and conditions of the Creative Commons Attribution license (http://creativecommons.org/licenses/by/3.0/). 